\title{
Innovation in Banking Industry: Achieving Customer Satisfaction
}

\author{
Clement Achimba1, Jared Opiyo Ongonga1, Samson Mecha Nyarondia1, \\ Amembah A. Lamu Amos', Michael Okwara2 \\ ${ }^{1}$ School of Business and Human Resource Development, Rongo University College, Rongo, Kenya \\ ${ }^{2}$ School of Education, Jaramogi Oginga Odinga University of Science and Technology, Bondo, Kenya \\ Email: rojejaksm@yahoo.com
}

Received 18 June 2014; revised 22 July 2014; accepted 5 August 2014

Copyright (C) 2014 by authors and Scientific Research Publishing Inc.

This work is licensed under the Creative Commons Attribution International License (CC BY). http://creativecommons.org/licenses/by/4.0/

(c) (i) Open Access

\section{Abstract}

This paper examines the effects of technology in the banking industry. Based on an expansive review of literature, the paper describes various factors in this area. Technology has a direct effect on the functioning of the banks. With technological advancement, the customers benefit and the bank gains by getting more clients. Most businesses desire to offer the best services, products and customer relations to their customers because these activities increase the retention rate of customers. These activities also have a direct effect on customer satisfaction. But it's the complexity of this process that brings a challenge to marketers. The paper looks at technological aspect of the process. This is because for any marketer or business practioner to succeed at managing a good customer relationship program, there is need for the adoption of supportive technology. This type of technology assists in the managing of the process through the maintainance of a customer data base, implementation and monitoring. Using a case study approach [1] shows that one of the business units she studied was able to achieve a $270 \%$ increase in business unit profits (above target) by implementing several straightforward Customer Relationship Management (CRM) measures. The paper analyses the nature of the banking industry and the role of technology in the Customer Relationship Management process and its implementation.

\section{Keywords}

Technology, Banking, Customer Relationship Management

\section{Introduction}

The banking industry is experiencing a transformation due to changes in consumer needs, behavior, knowledge

How to cite this paper: Achimba, C., Ongonga, J.O., Nyarondia, S.M., Amos, A.A.L. and Okwara, M. (2014) Innovation in Banking Industry: Achieving Customer Satisfaction. Open Journal of Business and Management, 2, 261-274. 
and competitive innovation as a result of globalization, libralisation and technological factors. Hence there is need for banks to adopt a culture of continuous Customer Relationship Management, customer research, learning, and business innovation. Organisations cannot afford to neglect these factors if they want to operate at their optimum level. Markets and customer demands are changing. Competitors activities are changing too and therefore to survive in this error of innovation, banks have to change their strategies. This is the reason why the banking industry has been trying to make their systems efficient and effective.

This paper considers technology as an important tool in the creation and management of customer relations because through technology banks can enhance their interactions with their customers and also build better customer relationships. However, to deliver an improved and in-depth understanding of customer's wants and needs, a fully integrated customer management system, along with a complete transparency, is required. In the emerging market scenario, for survival and growth, it is critical for a bank to align its vision, mission, goals and objectives with customer's satisfaction. Moreover, the future of any business lies in its excellent management of relationships. That is why customer's focus ought not to be viewed as just a business strategy but should become a corporate mission. Once good services are extended to customers, the loyal customers will work as ambassadors of the bank and facilitate the growth of the business. Good customer services in banks should have three basic tenets courtesy, accuracy and speed. Technology enables the bank to offer the later two (accuracy and speed), which enables the banks to offer quality products and services that are dynamic and hence improve customer satisfaction.

The analysis of the paper finds out that technology plays an important role in the implementation of a Customer Relationship Management program; especially in the banking industry. This is an important innovation to the banks. It means that if banks want to operate efficiently and effectively in their implementation of a CRM program, it's necessary for them to adopt technology as a supportive tool.

\section{Objectives of the Study}

The key objectives of this study are:

- To determine whether technology assists banks in the delivery of services, products and Customer Relationship Management;

- To evaluate the impact of technology on the banking industry;

- To determine whether technology improves customer satisfaction.

\section{Literature Review}

The banking industry is undergoing a rapid and radical transformation due to the all-pervasive influence of Information Technology (IT) and breath taking developments in the technology of telecommunications and electronic data processing. This process has radically altered the traditional ways of doing banking business and allowed banks to wipe out the difference in time, distance and speed. Many banks use state-of-the-art technology to provide their customers with better value-added services tailored to their needs. In this innovative error, there is no way a bank can remain lukewarm to technology and yet hope to grow. The choice is between survival and extinction but to survive in these times there is a need for the banks to adopt an innovative culture.

Proponents and theorists in this area still emphasize on a firms performance and customer value though they still talk about dual creation of a firm and value. Here we raise the question whether the fields focus on CRM sheds light on the understanding of customer firm behavior or whether it just creates more "heat", Because many vendors argue that CRM requires a paradigm shift in firm behavior (William, Richard 2005) [2]. The article also discusses that the key component of CRM should not be based on how to sell the product but rather on creating value for the firm (staying in existence) that is creating a long lasting relationship with the customer. CRM relies on this concept because it tries to find the specific elements of the exchange process that produce value to the customers. Bagozzi [3] refocused people's attention on the actual exchange process by re-interacting the fundamental economic concept that an exchange occurs only when both parties perceive that they are receiving value. But almost ten years after Berry [4] shifted the emphasis to the relationship between the company and the customer.

Using a case study approach Ryals [5] shows that one of the business unit she studied was able to achieve a $270 \%$ increase in business unit profits (above target) by implementing several straightforward CRM measures. Using a multiform (cross-sectional) database, Srinivasan and Moorman [6] show that firms that invest more in 
CRM activities and technology have greater customer satisfaction. Other proponents show that if the firm performance is measured in terms of retention and customer satisfaction, there is a greater retention and satisfaction levels for firms that have good relational information process in place. Satish, Subhash, Peter and Pushkala [7] in their studies on: Say that essentially customer relationship orientation establishes a "collective mind". Weick and Roberts [7] believe that the system is important for the organization and that customer relationship is an asset and a driver of choice in the process information processing and implemenatation.

Some thinkers agree that the potential of today's customer information marketing systems far exceeds any traditional marketing information system that has gone before. These new systems differ from the old in their scale (thousands of bits of information on tens of millions of customers), the depth of information that can be captured on each individual or household and the ways in which the information can be used. They continue by stating that in many cases, access to this information about individual customers allows the organization to customize to the individual level what previously would have been undifferentiated services.

In recent years, sophisticated CRM software has helped make quality service achievable and efficient. CRM is also revolutionizing the sales function. By providing detailed customer histories, integrated service, and pricing information, these tools allow the sales person to be consultative and to add more value than in the past. They also point out the drawbacks of CRM systems:

They require major monetary and human investments; they often mandate integration of incompatible information systems, significant internal training costs, and incentives to ensure they are used effectively. Frequently they fail at least on the initial try, because some companies do not anticipate the amount of work involved and many do not realize how resistant their employees will be to making necessary changes. But despite these drawbacks, many companies now see the implementation of front office CRM as not only a potential competitive advantage but also, in some cases, a requirement for survival.

Technological plan aligns the bank's information system investments and initiatives with its business strategy. Against the background of financial liberalization in India on one hand, and the continuous changes taking place in IT products on the other hand, banks are entering into newer areas of mutual funds, merchant banking factoring leasing and financial counseling. Thus Indian banks feel the need to work out their future strategies in the changed context and the emerging environment. Banking is no more a business related to only money transactions it is now perceived as business related to information on financial transactions.

In the banking sector many banks operate through networks this enables speedy inter-bank transactions, hence customers can utilize services like credit and debit cards easily. Computers are no longer used for operational efficiency but to improve customer services.

Uppal [7] notes that more than other industries, financial institutions rely on gathering, processing, analyzing and providing information in order to meet the needs of customers. Hence there is a need for banks to adopt an automated information processing technology. Services include Automated teller machines ATM's, smart cards home banking, tele-banking, internet banking core banking-centralized database, only one sever HUB MIS management information system quick accurate decisions, electronic clearing service across cities, bulk payments. The services have enabled the bank to: save time, increase storage capacity, save money, improve data accuracy, and maintain data security. Consumer e-banking has also enabled the banks to offer round the clock banking services and increase profitability, convenient banking, speed banking, low cost banking, quality banking services and virtual banking. There has been a change in the delivery of services to customers due to technological changes.

\section{The Customer Relations Process}

Specifically CRM relates to strategy: the management of the dual creation of value, the intelligent use of data and technology, the acquisition of customers knowledge and the diffusion of this knowledge to the appropriate stakeholders. It also includes the development of appropriate (long-term) relationships, with specific customers and the integration of processes across many areas of the firm and also across the network of firms that collaborates to generate customer value.

Glazer [8] argues that customer relationship management applications facilitate organizational learning about the customer by enabling the analysis of purchase behavior across transactions through different channels and customer touch points. He provides examples of how FedEx and American airlines used investments in IT systems at the customer interface to gain valuable customer knowledge. 
Firms with greater deployment of CRM applications are in a greater position to leverage their stock, accumulated knowledge and experience into valuable customer support process. In addition, firms with a greater deployment of CRM applications are likely to be more familiar with the data management issues involved in initiating, maintaining and terminating a customer relationship. This familiarity gives a firm a competitive advantage in leveraging their collection of another customer data to customize offerings and to customer needs.

CRM applications also enable contact employees to record relevant information about each customer transaction. After this information is captured, it can be processed and converted into customer knowledge based on information-processing rules and organizational policies. Customer knowledge captured across service encounters can then be made available for all future transactions enabling employees to respond to any customer need in a contextual manner. Firms too can use customer knowledge to profile customers and identify their needs based on similarities between their purchase behaviors and those of other customers [9]. Firms can share their accumulated customer knowledge with customers to enable them serve them by defining the service and its delivery to suit their needs. The process of customer self-selection of service feature provides additional opportunities for firms to learn their customers evolving needs and to deepen their customer knowledge.

A customer centric organization should consist of structural aspects that ensure that organizational actions are driven by customer needs and not by the internal concerns of functional areas. In addition, employee evaluation schemes and incentives should be designed to encourage behaviors consistent with a customer relationshiporiented culture by augmenting the organizations ability to focus on customer interactions and by ensuring that expertise from different functional areas are deployed to promote quality customer experience. These can be achieved by providing quick and effective responses to customers. The use of relational information is also likely to enhance customer satisfaction by proving consumption-related fulfillment [10]. Apart from shaping responses from customers, by enabling customers to communicate easily with the organization, relational information process helps register customer's complaints and provide them feedback. In addition, the integration of customer information and the sharing of it with key customer contact employees enables customers and other stakeholders to communicate with firms more effectively.

Further, other proponents state that frequent and open communication between a supplier and a customer improves the customer's efficiency in using the firm's products or services, thereby improving customer satisfaction and loyalty. Relationship information process may also boost customer relationship learning by proving customers with greater understanding of organizations attempts to respond to their demands and enhancing customer satisfaction and loyalty [11]. Still others say that the primary goal for a firm to implementing CRM applications is to track customer behavior, to gain insight into customer tastes and evolving needs.

Adrian and Pennie [12] state that CRM should comprise a small set of processes that addresses tasks critical to the achievement of organizations goals, second each process should contribute to the value creation process at the strategic or macro level. Fourth, the process needs to manifest interrelationships.

They list five processes of CRM:

a) The strategy development process.

b) The value creation process.

c) The multi-channel integration process.

d) The performance assessment process.

For value creation, it is necessary to determine how existing and potential customer profitability varies across different customers and customer segments. Secondly, the economics of customer acquisition and customer retention and opportunities for cross-selling up-selling and building customer advocacy must be understood. How these elements contribute to increasing customer lifetime value is integral to value creation. Calculating the customer lifetime value of different segments helps the organization to focus on the most profitable customers segments.

The value process is important because it translates business and customer strategies into specific value proposition statements that are delivered to customers and thus, it explains what value is to be received by the organization, including the potential for co-creation.

\section{Research Methodology}

This study used both primary and secondary data.

Two Self-Appraisal Reports for the banks and customers were used to obtain primary data relating to relationship management in the banking system. Management personnel perceptions regarding relationship man- 
agement in the banking sectors were obtained by use of a questionnaire.

The questionnaire items used were derived from reviewed literature. Different feedback information from bank managers and customers was obtained using rating scales of 1 - 5, 1 - 7 and open ended questions.

\section{Data and Discussion}

\section{Respondents age}

In the research question that sought to find out the respondents age, Table 1 shows the age distribution of the respondents.

Ranking age $1>20-30,2>30-40,3>40-50,4>50$ and above

From Table 1, the data shows that most managers were below the age of 40 .

\section{Opening a bank account and age}

In the research question which sought to find out the relationship between opening a bank account and age.

Table 2 shows the respondents' views regarding ease of opening an account.

Ranking: Very simple 5, 4, 3, 2, 1 Very difficult

Table 2 shows that $100 \%$ of the respondents said that it was either simple or very simple to open a bank account.

\section{Ease in accessing a bank account and age}

In the research question which sought to look at the ease of a customer accessing their bank account, the following data was obtained.

\section{Ranking: Very simple 5, 4, 3, 2, 1 Very difficult}

Table 3 shows that $100 \%$ of the managers agreed that it's either simple or very simple for the customers to access their account because technology for example ATM'S.

Table 1. Respondent's age.

\begin{tabular}{ccc}
\hline & Frequency & Percent \\
\hline $20-30$ & 10 & 43.5 \\
$30-40$ & 8 & 34.8 \\
$40-50$ & 4 & 17.4 \\
50 and above & 1 & 4.3 \\
Total & 23 & 100.0
\end{tabular}

Table 2. How easy is it to open a bank account * respondents age cross tabulation.

\begin{tabular}{ccccccc}
\hline & \multicolumn{5}{c}{ Respondents } \\
How easy is it to open A bank account? & $20-30$ & $30-40$ & $40-50$ & 50 and above & Total \\
\cline { 2 - 6 } Simple & 5 & 7 & 3 & 15 \\
Very simple & 5 & 1 & 1 & 1 & 8 \\
Total & 10 & 8 & 4 & 1 & 23 \\
\hline
\end{tabular}

Table 3. How easy is it for a customer to access their account * respondents age cross tabulation.

\begin{tabular}{ccccc}
\hline \multirow{2}{*}{$\begin{array}{c}\text { How easy is it for customers } \\
\text { to access their accounts? }\end{array}$} & $20-30$ & $30-40$ & $40-50$ & Respondents age \\
\cline { 2 - 5 } Simple & 1 & 2 & 4 & and above \\
Tery simple & 9 & 6 & 1 & 16 \\
Total & 10 & 8 & 4 & 1 \\
\hline
\end{tabular}




\section{Complexities in the documentation process and age}

In the research question which sought to find out whether there was any complexity in the documentation process with age, the following data was obtained as shown below from the managers.

Rankings 5-very complex, 4-much complex, 3-complex, 2-not so complex, 1-not at all complex.

From Table 4, it can be observed that most managers felt that the documentation process wasn't so complex while opening a bank account, while age wise the older managers felt it was complex.

Customization of services

In the research question which sought to find out whether banks customized there services, the results are shown in Table 5.

Table 5 shows that more banks customize their products $95 \%$. But only $10 \%$ said NO. It can be concluded that both banking industries have a customer focused approach.

\section{Having a relational program}

In the research question which sought to find out whether there was a relationship between having a relational program and value of customer relations, the following data was obtained as shown in Table 6.

It can be observed from Table 6 that many banks had relational programs that is $86 \%$ (20 of 23), they also considered customer relations to be of more value because $78 \%$ (18) of the number of those who said no still concurred that customer relations had too much value to them.

\section{CRM targeted or general}

In the research question which sought to find out whether CRM was targeted or general, the findings are shown in Table 7.

$5>$ very much targeted, $4>$ much targeted, $3>$ targeted, $2>$ not so targeted, $1>$ general.

From Table 7, it is clear that customer relations management is much targeted, with 10 respondents or, $43 \%$ of the managers saying that they considered customer relations to be of too much value. Good customer relation programs must have the customer as the main focus the rule of $20 / 80$ says that $20 \%$ customers bring in more

Table 4. How easy is it to open a bank account* respondents age cross tabulation.

\begin{tabular}{cccccc}
\hline \multirow{2}{*}{$\begin{array}{c}\text { Documentation process } \\
\text { while opening an account }\end{array}$} & $20-30$ & $30-40$ & $40-50$ & 50 and above & total \\
\cline { 2 - 5 } Complex & 6 & 2 & 1 & 3 \\
Not so complex & 6 & 1 & 1 & 13 \\
Not at all complex & 4 & & 2 & 1 & 23 \\
Total & 10 & 8 & 4 & & 7 \\
\hline
\end{tabular}

Table 5. Do you customize services?

\begin{tabular}{ccc}
\hline Do you customize services & Frequency & Percent \\
\hline Yes & 22 & 95.5 \\
No & 1 & 4.3 \\
Total & 23 & 100.0 \\
\hline
\end{tabular}

Table 6. Do you have a relation program * value customer relations cross tabulation.

\begin{tabular}{cccc}
\hline & \multicolumn{2}{c}{ Value customer relations } & Total \\
\cline { 2 - 4 } Do you have a relation program? & Much & Too much & 20 \\
Yes & 4 & 16 & 3 \\
Total & 1 & 2 & 23 \\
\hline
\end{tabular}


Table 7. Is your CRM target or general? * value customer relations cross tabulation.

\begin{tabular}{cccc}
\hline \multirow{2}{*}{ Is your CRM target or general? } & \multicolumn{2}{c}{ Value customer relations } & Total \\
\cline { 2 - 3 } General & Much & Too much & 10 \\
Targeted & 3 & 7 & 5 \\
Much targeted & 2 & 3 & 3 \\
Very much targeted & & 3 & 5 \\
Total & 5 & 5 & 23 \\
\hline
\end{tabular}

profit than the rest $80 \%$. Hence it can be assumed that a targeted customer relations program can be more effective than a general one.

\section{Employees get rewarded for good customer relationship handling}

In the research question which sought to find out whether there was a relationship between employees rewards and value for customer relations. Table 8 summarizes the outcome of the enquiry.

$5>$ always, $4>$ most of the time, $3>$ some of the time, rarely, $2>$ rarely, $1>$ never:

Table 8 shows that banks rewarded their employees for good customer handling, but because they considered customer relations to be too much important. Due to this 13 bank managers said that they always rewarded employees.

\section{Effectiveness of CRM programs}

In the research question which sought to find out the effectiveness of CRM programs and value for customer relations, the results are indicated in Table 9.

Very effective 5, 4, 3, 2, 1 Very ineffective:

Table 9 shows that there was too much emphasis on customer relations in the banks and their relationship management was effective.

\section{Simple or complicated CRM software}

In the research question which sought to find out whether the CRM installed was complicated, the results are shown in Table 10.

The data in Table 10 shows that few banks used the CRM software. That is 12 of 23 with one bank saying that it was complicated to use the software. It is assumed that having CRM software makes customer relationship management easier, hence efficiency and effectiveness in service delivery. Customer management can be effected through technology easily especially customer profiling.

\section{Simple to operate the software}

In the research question which sought to find out whether the software installed in the bank was simple to operate, the data in Table 11 was obtained:

Very simple: 5, 4, 3, 2, 1, Very difficult

Table 11 shows that bank managers found it simple to operate the software. This can be attributed to the ease of doing things like opening a bank account and accessing a bank account.

\section{Efficiency as result of technological change}

In the research question which sought to find out the impact of technological change on efficiency, the results are shown in Table 12.

5 > excellent, 4 > very good, 3 > good, $2>$ fair, $1>$ poor:

Table 12 shows that technology plays a role in the efficiency of service delivery. Technological change enables speed in delivery, profiling customers and their needs plus other relationship management activities which promote efficiency and effectiveness.

\section{Consider customer relations important}

In the research question which sought to find out whether customer relations was important and having a relational program. The results are shown in Table 13.

According to Table 13, 20 out of 23 bank managers said they considered customer retention an important issue but 3 said they didn't have a relational program. This activity is undertaken by the relations program as mounted by the banks. Having a relational program helps the bank to know how go about with relationship 
Table 8. Employees get rewarded for good customer relationship handling * value customer relations cross tabulation.

\begin{tabular}{cccc}
\hline \multirow{2}{*}{$\begin{array}{c}\text { Employees get rewarded for } \\
\text { good customer relationship handling }\end{array}$} & \multicolumn{2}{c}{ Value customer relations } & \multirow{2}{*}{ Total } \\
\cline { 2 - 3 } Rarely & Much & Too much & \\
Some of the time & 1 & & 1 \\
Most of the time & 1 & 3 & 4 \\
Always & 2 & 3 & 5 \\
Total & 1 & 12 & 13 \\
\hline
\end{tabular}

Table 9. How effective are your CRM programs * value customer relations cross tabulation.

\begin{tabular}{cccc}
\hline \multirow{2}{*}{ How effective are your CRM programmes } & \multicolumn{2}{c}{ Value customer relations } & \multirow{2}{*}{ Total } \\
\cline { 2 - 3 } & Much & Too much & \\
\hline Effective & 4 & 5 & 9 \\
Very effective & 1 & 13 & 14 \\
Total & 5 & 18 & 23 \\
\hline
\end{tabular}

Table 10. Simple or complicated * have CRM software installed cross tabulation.

\begin{tabular}{ccc}
\hline & Have CRM software installed & Total \\
\cline { 2 - 3 } & Yes & 12 \\
Simple or complicated Simple & 12 & 12 \\
\hline
\end{tabular}

Table 11. How simple is it to operate the software * have CRM software installed cross tabulation.

\begin{tabular}{ccc}
\hline \multirow{2}{*}{ How simple is it to operate the software } & Have CRM software installed & Total \\
\cline { 2 - 3 } & Yes & 7 \\
Simple & 7 & 5 \\
Very simple & 5 & 12 \\
Total & 12 & \\
\hline
\end{tabular}

Table 12. Efficiency as a result of technological change.

\begin{tabular}{ccc}
\hline Efficiency as a result of technological change & Frequency & Percent \\
\hline Good & 3 & 13.0 \\
Very good & 13 & 56.5 \\
Excellent & 7 & 30.4 \\
Total & 23 & 100.0 \\
\hline
\end{tabular}

Table 13. Consider customer retention as an important issue * do you have a relation program? Cross tabulation.

\begin{tabular}{ccc}
\hline Do you consider customer retention as an important issue? & Do you have a relational program? & No \\
\cline { 2 - 3 } Yes & Yes & 3 \\
Total & 20 & 3 \\
\hline
\end{tabular}


building and sustenance, banks having a relational program have a likelihood of retaining most of their customers if not all.

\section{CRM activities have helped the bank to retain customers}

In the research question which sought to find out whether CRM activities helped the bank to retain their customers, the following were the findings as shown in Table 14.

Table 14 shows that customer relationship management activities have helped banks. All banks even those which did not have relational programs accepted that these activities helped them to retain their customers. It can be assumed that CRM activities helped banks to retain and maintain their customers.

\section{Effectiveness of the CRM programs}

In the research question which sought to find out whether CRM activities were effective and having a relational program. The findings are shown in Table 15.

Very effective 5, 4, 3, 2, 1 Very effective:

Table 15 shows that most managers felt that their CRM activities were effective all 23 banks confirmed this. The success can be attributed to having a relational program because banks which had these programs were much more effective.

\section{Efficiency as result of technological change}

In the research question which sought to find out whether there was efficiency as a result of technological change in reference to the last 10 years, the following were the findings as shown in Table 16.

$5>$ excellent, $4>$ very good, $3>$ good, $2>$ fair, $1>$ poor:

Table 16 shows the relationship between efficiency as result of technological change and its effects in the last ten years. A large number of banks felt that technology had changed the banking system in the last 10 years 21 of the 23 banks said yes. On the other hand majority of the banks also acknowledged the efficiency in the bank as result of technological change.

Table 14. Has CRM activities helped your bank to retain customers * do you.

\begin{tabular}{ccccc}
\hline & & \multicolumn{2}{c}{ Do you have a relation banking? } \\
\cline { 2 - 3 } Have CRM activities helped your bank to retain customers & Yes & No & \\
\cline { 3 - 4 } Yes & 20 & 3 & 23 \\
Total & 20 & 3 & 23
\end{tabular}

Table 15. How effective are your CRM programs.

\begin{tabular}{ccc}
\hline & Frequency & Percent \\
\hline Effective & 9 & 39.1 \\
Very effective & 14 & 60.9 \\
Total & 23 & 100.0 \\
\hline
\end{tabular}

Table 16. Efficiency as result of technological change * has technology changed the banking system for the last 10 years cross tabulation.

\begin{tabular}{cccccc}
\hline \multirow{2}{*}{$\begin{array}{c}\text { Efficiency as a result } \\
\text { of technological change }\end{array}$} & \multicolumn{2}{c}{ Has technology changed the banking system for the last 10 years? } & & Total \\
\cline { 2 - 5 } Good & Too little & Not so much & Much & Too much & \\
\hline $\begin{array}{c}\text { Very good } \\
\text { Excellent }\end{array}$ & 1 & 1 & 2 & 6 & 13 \\
Total & 1 & 1 & 2 & 5 & 7 \\
\end{tabular}




\section{Customer response to technology}

In the research question which sought to find out customers response on technology with the effect it has on the banking system in the last 10 years, the findings are shown in Table 17.

5 excellent, $4>$ very good, $3>$ good, $2>$ fair, $1>$ poor:

Table 17 shows that a large number of managers felt that customer's response to technology was either good or excellent. The goodness of customers towards technology can be attributed to the change in technology in the last ten years. Most customers use technology much in different ways because it's fast and makes service delivery easier. For example, use of ATM booths, mobile and credit cards all these services require technology.

\section{To what extent the bank offered trust and privacy}

In the research question which sought to find out to what extent the bank offered trust and privacy to their customers, the findings are shown in Table 18.

5 > always, $4>$ most of the time, 3 > sometimes, $2>$ rarely, $1>$ never:

Table 18 shows that a large number of customers, i.e. $58 \%$ felt that banks offered them privacy always. In any relationship, it was always important for trust and privacy to be practiced by the parties involved. It enhances a relationship and creates business value through word of mouth because a satisfied customer.

\section{Having a liking for customer care programs}

In the research question which sought to find out whether customers had a liking for customer care programs in bank in relation to being satisfied with the bank's communication channels, the results are shown in Table 19.

Table 17. How is the customer response to technology * has technology changed the banking.

\begin{tabular}{ccccc}
\hline \multirow{2}{*}{$\begin{array}{c}\text { How is the customer } \\
\text { response to technology }\end{array}$} & Has technology changed the banking system for the last 10 years & Total \\
\cline { 2 - 3 } Fair & Too little & Much & Too much & \\
Good & 1 & 4 & 1 & 5 \\
Very good & 1 & 3 & 8 & 12 \\
Exellemt & & 2 & 2 & 4 \\
Total & 1 & 10 & 11 & 22 \\
\hline
\end{tabular}

Table 18. To what extent does your bank offer you trust and privacy?

\begin{tabular}{ccc}
\hline To what extent does your bank offer you privacy and trust? & Frequency & Percent \\
\hline Never & 3 & 1.4 \\
Rarely & 7 & 3.2 \\
Some of the time & 14 & 6.4 \\
Most of the time & 67 & 30.5 \\
Always & 129 & 58.6 \\
Total & 220 & 100.0 \\
\hline
\end{tabular}

Table 19. Do you like the banks customer care programs * satisfied with the banks communication.

\begin{tabular}{|c|c|c|c|c|c|c|}
\hline \multirow[b]{2}{*}{$\begin{array}{l}\text { Do you like the banks } \\
\text { customer care programs }\end{array}$} & \multicolumn{5}{|c|}{ Satisfied with the banks communication channels } & \multirow[b]{2}{*}{ Total } \\
\hline & Highly dissatisfied & Dissatistied & Not so satisfied & Satisfied & $\begin{array}{l}\text { Highly } \\
\text { satisfied }\end{array}$ & \\
\hline Not at all & & 2 & 1 & 1 & & 4 \\
\hline Not so much & & 18 & 3 & 30 & 2 & 53 \\
\hline Much & & 13 & 2 & 65 & 6 & 86 \\
\hline Very much & 1 & & & 13 & 5 & 19 \\
\hline Very very much & & 3 & & 29 & 26 & 58 \\
\hline Total & 1 & 36 & 6 & 138 & 39 & 220 \\
\hline
\end{tabular}


5 > Very very much, $4>$ very much, $3>$ much, $2>$ not so much, $1>$ not at all:

Table 19 shows that a large number of customers liked the banks customer care programs. This can be compared to the satisfaction with the banks communication channels. Basically customer care programs involve a lot of dialogue which if delivered in an effective and efficient way can create value for the bank

Banks ability to deal with customer complaints

In the question which sought to find out the bank's ability to deal with customer complaints and how satisfied customers were with the communication channels. This is shown in Table 20.

5 > excellent, $4>$ very good, $3>$ good, $2>$ fair, $1>$ poor:

Table 20 shows that most customers found the bank's ability to deal with customer complains well and they were satisfied with its communication channels too. Hence this sign of effectiveness and efficiency. This satisfaction can be attributed to relationship management practices by the banks today, knowing the customers and their needs.

\section{Find support centers effective}

In the research question which sought to find out whether customers found support centers effective and were satisfied with the banks communication channels, the findings are shown in Table 21.

$5>$ very much effective, $4>$ much effective, $3>$ effective, $2>$ not so supportive, $1>$ not at all supportive:

Table 21 shows that a large number of customers found support centers effective and they were satisfied too with the banks communication channels. Support centers like call centers do help the bank to be effective and efficient.

\section{Interest in developing a relationship with the bank}

In the question which sought to find out whether customers were interested in developing a relationship with the bank, the following were the results as shown in Table 22.

$5>$ very interested, $4>$ much interested, $3>$ interested, $2>$ fairly interested, $1>$ not interested.

Table 22 shows that a large number of customers were interested in developing a relationship with the bank. Only few customers said they were not interested. Customer interest in the development of a relationship is sign that banks were practicing relationship management activities.

Heard about customer relationship management

In the question which sought to find out whether customer's had knowledge about customer relationship management CRM the following were the results as shown in Table 23.

Table 20. Ability to deal with customer complaints * satisfied with the banks communication channels.

\begin{tabular}{|c|c|c|c|c|c|c|}
\hline $\begin{array}{l}\text { Banks ability to deal with } \\
\text { customer complaints }\end{array}$ & $\begin{array}{c}\text { Highly } \\
\text { dissatisfied }\end{array}$ & Dissatisfied & $\begin{array}{c}\text { Not } \\
\text { so satisfied }\end{array}$ & Satisfied & $\begin{array}{l}\text { Highly } \\
\text { satisfied }\end{array}$ & Total \\
\hline Poor & & 2 & 1 & 3 & 1 & 7 \\
\hline Fair & & 10 & 1 & 13 & 3 & 27 \\
\hline Good & & 22 & 4 & 65 & 1 & 92 \\
\hline Very good & 1 & 2 & & 39 & 16 & 58 \\
\hline Excellent & & & & 18 & 18 & 36 \\
\hline Total & 1 & 36 & 6 & 39 & 39 & 220 \\
\hline
\end{tabular}

Table 21. Find support centers effective satisfied with the banks communication channels.

\begin{tabular}{|c|c|c|c|c|c|c|}
\hline $\begin{array}{c}\text { Find support centers } \\
\text { effective }\end{array}$ & Highly dissatisfied & Dissatisfied & $\begin{array}{c}\text { Not } \\
\text { so satisfied }\end{array}$ & Satisfied & $\begin{array}{l}\text { Highly } \\
\text { satisfied }\end{array}$ & Total \\
\hline Not at all supportive & & 1 & & 1 & 2 & 4 \\
\hline Not so supportive & & 13 & 2 & 23 & 5 & 43 \\
\hline Effective & 1 & 17 & 3 & 70 & 9 & 100 \\
\hline Much effective & & 4 & 1 & 35 & 13 & 53 \\
\hline Very much effective & & 1 & & 8 & 10 & 19 \\
\hline Total & 1 & 36 & 6 & 137 & 39 & 219 \\
\hline
\end{tabular}


Table 22. Interested in developing a relationship with the bank.

\begin{tabular}{ccc}
\hline Interested in developing a relationship with the bank? & Frequency & Percent \\
\hline Not interested & 8 & 3.6 \\
Fairly interested & 6 & 2.7 \\
Interested & 65 & 29.5 \\
Much interested & 67 & 30.6 \\
Very interested & 74 & 33.6 \\
Total & 220 & 100.6 \\
\hline
\end{tabular}

Table 23. Heard about customer relationship management (CRM).

\begin{tabular}{ccc}
\hline Heard about customer relationship management & Frequency & Percent \\
\hline Yes & 93 & 42.3 \\
No & 127 & 57.7 \\
Total & 220 & 100.0 \\
\hline
\end{tabular}

Table 23 reporting on the customer's response about CRM shows that many customers said NO to the question inquiring whether they heared about Customer Relations Management (CRM). Customer Relationship Management as a program or even software is practiced by almost every institution but the difference is the procedures and names used in reference to it. It can assumed that customers who heard about CRM were involved in a relationship with a bank which has focus on customer relationship as a program or strategy, but again the customer might have heard about CRM from somewhere else like the media.

Find the software installed in the ATM booth user friendly

In the question which sought to find out whether customers found the software installed in the ATM booth user friendly. The following were the results as shown in Table 24.

$5>$ very very much user-friendly, $4>$ very much user-friendly, $3>$ much user-friendly, not so user friendly, $1>$ not user friendly:

Table 24 shows that a large number of customers had an ATM card. In addition to having an ATM card most customers said that the software installed in the booth was much user friendly. An ATM is supposed to be utilized as a delivery tool at any time on behalf of the bank; because of this most ATM's are made with the best human touch in the best way possible. From Table 24, it can be concluded that customers who found it easier to operate their respective ATM booths were likely to have better relations with the bank in general. This comes as a result of the technological era where everything is done in an easy and fast way. A customer needs a service to be offered to him right away, hence this improves customer relations.

Rate the CRM software

In the research question which asked the customers to rate the software installed in the ATM booth and having an ATM card, the following were the results as shown by Table 25.

5 > excellent, 4 > very good, 3 > good, 2 > fair, $1>$ poor:

Table 25 shows that most customers had an ATM card and felt that the software installed in the booth was good some even said it was excellent, apart from some who said it either fair or poor but this number was lower. Hence from the tables it can be assumed that customers did enjoy using the software. Ease in a relationship enhances it, so it be said that customers are likely to continue or want to develop a relationship with a bank which had ease in accessibility of their services.

\section{Delivery program preferred}

In the question which sought to find out the preferred delivery channel by customers and having an ATM card. The results are shown by Table 26.

Table 26 shows that most customers who had an ATM card preferred to use an ATM booth instead of going to the bank. Some of the reasons for this can be its time saving, faster convenient or it's easier to operate. Quick service is a necessary factor while offering a service. 
Table 24. Find the software installed in the ATM booth user friendly * have an ATM.

\begin{tabular}{ccc}
\hline \multirow{2}{*}{ Find the software in the ATM booth user friendly } & Have an ATM & Total \\
\cline { 2 - 3 } Not user friendly & Yes & 5 \\
Not so user friendly & 10 & 10 \\
Much user friendly & 6 & 6 \\
Very much user friendly & 95 & 95 \\
Very very much user friendly & 81 & 81 \\
Total & 197 & 197 \\
\hline
\end{tabular}

Table 25. Rate the CRM software * have an ATM.

\begin{tabular}{ccc}
\hline \multirow{2}{*}{ Rate the CRM software } & Have an ATM & Total \\
\cline { 2 - 3 } & Yes & 3 \\
Poor & 3 & 4 \\
Fair & 4 & 62 \\
Good & 62 & 85 \\
Very good & 85 & 43 \\
Excellent & 43 & 197 \\
\hline
\end{tabular}

Table 26. Which delivery program do you prefer * have an ATM.

\begin{tabular}{cccc}
\hline & \multicolumn{2}{c}{ Have an ATM } & \multirow{2}{*}{ Total } \\
\cline { 2 - 3 } Which delivery program do you prefer? & Yes & No & \\
\hline Bank & 9 & 17 & 26 \\
ATM & 188 & 6 & 194 \\
Total & 197 & 23 & 220 \\
\hline
\end{tabular}

\section{Conclusions}

The current economic environment calls for aggressiveness. This is because customers are more knowledgeable, have a variety to choose from, have more money and there is high competition from other companies. For the company to stay ahead of the market and be a market-oriented one, it needs to go where their customers are (technology enable/oriented). Technology can enable the company to offer good customer services as long as it has appropriate technology. It can also help the company to offer reliable and prompt service for example ATM's, Mobile Banking and On-Line Banking. The use of technology also enables the company to offer customized products and service by using the collected customer data e.g. using a CRM software. A business operating in a market with low competitor dynamism will benefit most from technology. This is because technology is a vital element of a bank's competitive advantage especially in the process of Customer Relations Management.

In the modern business environment leading customer-driven companies establish measurement and feedback systems that allow them to chart the rate of their success and to guide their continuous improvement initiatives. They recognize the importance of monitoring their performance in meeting evolving customer expectations and implementing and initiating changes when appropriate. Hence there is need for the organization to adopt a consistent customer relationship culture that is up to date with the market and consumer changes. This is worth con- 
sidering that the rate of research, innovation and development is taking place in the marketplace. The challenge for financial institutions today is to deliver the best service experience while saving on cost. Hence organizations will experience difficulties while adopting this type of technological support system. But despite these hurdles, technology is not an option for any organization that wants to have a working CRM process that is effective and efficient.

\section{References}

[1] Ryals, L. (2005) Making Customer Relationship Management Work: The Measurement and Profitable Management of Customer Relationships. Journal of marketing, 69, 252-261. http://dx.doi.org/10.1509/jmkg.2005.69.4.252

[2] Boulding, W., Staelin, R., Ehret, M. and Johnson, W.J. (2005) A Customer Relationship Management Roadmap: What Is Known, Potential Pitfalls and Where to Go. Journal of Marketing, 69, 155-166. http://dx.doi.org/10.1509/jmkg.2005.69.4.155

[3] Bagozzi, R.P. (1974) Marketing as an Organized Behavioral System of Exchange. Journal of Marketing, 38, 77-81. http://dx.doi.org/10.2307/1250397

[4] Berry, L.L., Lynn and Upah, G. (1985) Relationship Marketing of Services: Growing Interest, Emerging Perspectives. Journal of the Academy of Marketing Services, 23, 236-245.

[5] Morgan, R.M and Hunt, S. (1994) The Commitment-Trust Theory of Relationship Marketing. Journal of Marketing, 58, 20-38. http://dx.doi.org/10.2307/1252308

[6] Jayachandra, S., Sharma, S., Kaufman, P. and Raman, P. (2005) The Role of Information Process and Technology Use in Customer Relational Management. American Marketing Association Journal, 69,177-192.

[7] Weick, K.E. and Robert, K.H. (1994) Collective Mind in Organization: Heedful Interrelating on Flight Decks. Administrative Science Quarterly, 38, 357-383. http://dx.doi.org/10.2307/2393372

[8] Glazier, R. (1991) Marketing in an Information Intensive Environment: Strategic Implications of Knowledge as an Asset. Journal of Marketing, 55, 1-19. http://dx.doi.org/10.2307/1251953

[9] Prahalad, C.K., Krishnan, M.S. and Mithas, S. (2005) Customer Relationships: The Technology Customer Disconnect. Optimize. http://www.optimizemag.com/0.4/customer.htm

[10] Oliver, R.L. (1996) Satisfaction: A Behavioral Perspective on the Consumer. Richard D. Irwin/McGraw-Hill, Boston.

[11] Fred, S. and Sallis, J. (2003) Promoting Relationship Learning. Journal of Marketing, 67, 80-96. http://dx.doi.org/10.1509/jmkg.67.3.80.18656

[12] Adrian, P. and Pennie, F. (2005) A Strategic Framework for Customer Relationship Management. Journal of Marketing, 69, 167-176. 
Scientific Research Publishing (SCIRP) is one of the largest Open Access journal publishers. It is currently publishing more than 200 open access, online, peer-reviewed journals covering a wide range of academic disciplines. SCIRP serves the worldwide academic communities and contributes to the progress and application of science with its publication.

Other selected journals from SCIRP are listed as below. Submit your manuscript to us via either submit@scirp.org or Online Submission Portal.
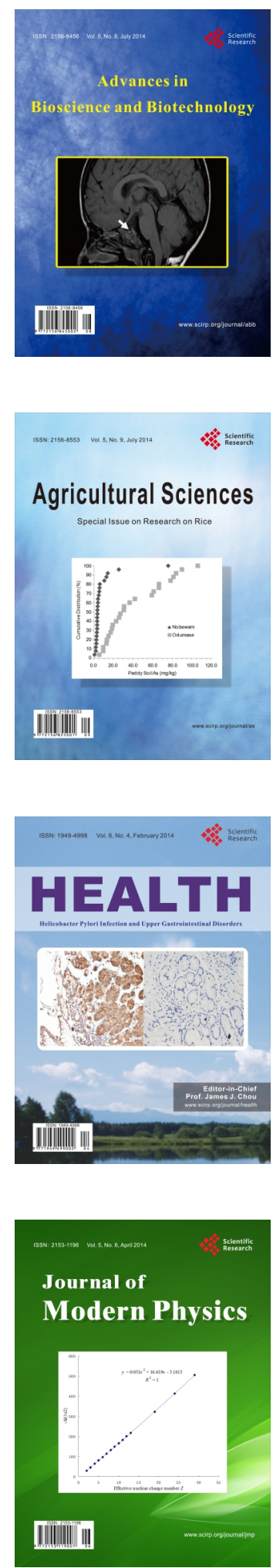
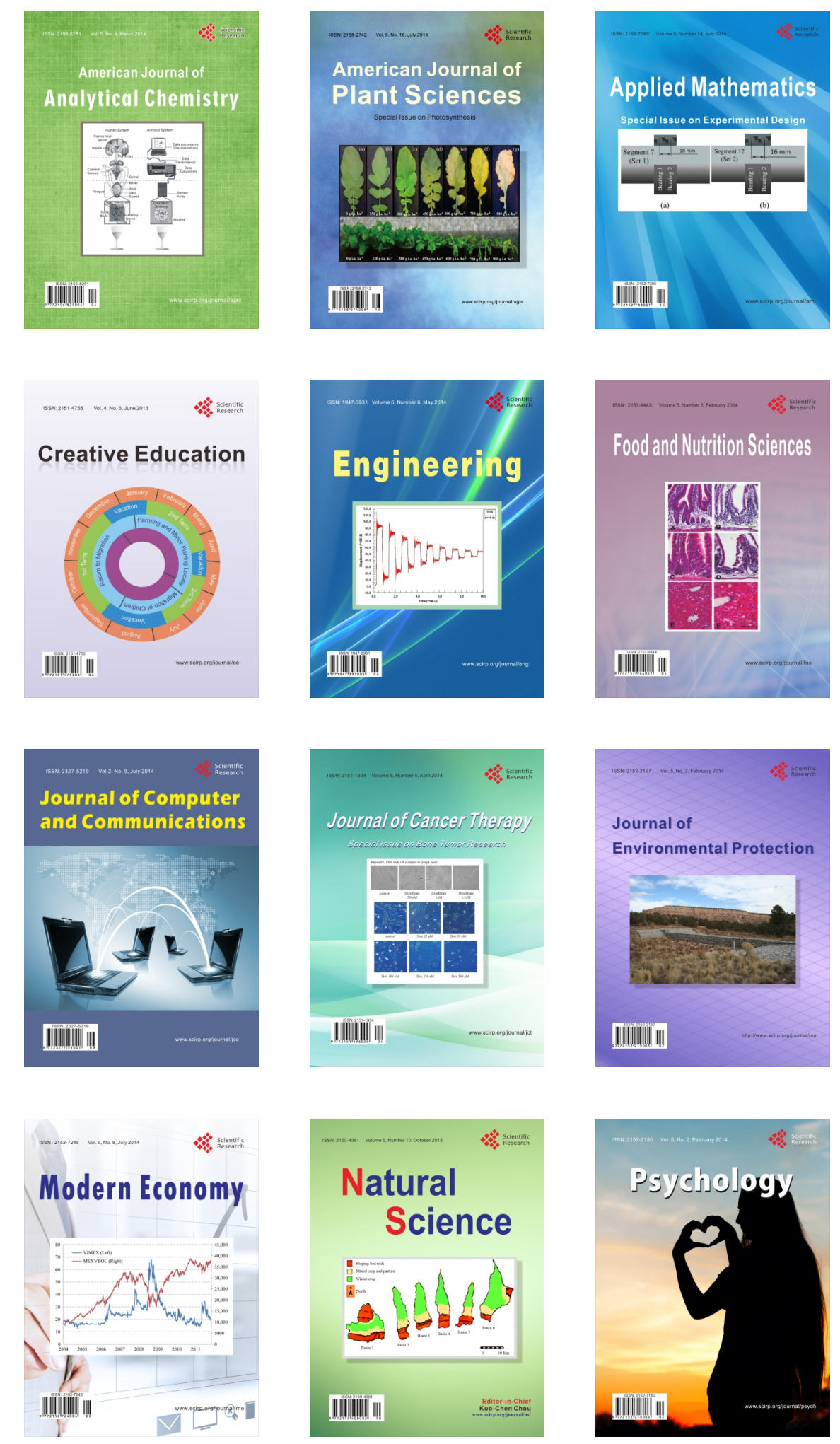